\title{
Theoretical Prediction of Air Pollutants from Diesel Utilization at Base Transceiver Stations in Local Government Areas of Abia State, Nigeria
}

\author{
${ }^{1 *}$ Salami L., ${ }^{2}$ Akinbomi J.G., ${ }^{2}$ Adebanjo, S.A. and ${ }^{3}$ Folami, N.A \\ ${ }^{1}$ Environmental Engineering Research Unit, Department of Chemical and Polymer Engineering, Lagos State \\ University, Epe, Lagos State, Nigeria. \\ ${ }^{2}$ Department of Chemical and Polymer Engineering, Lagos State University, Epe, Lagos State, Nigeria. \\ ${ }^{3}$ Department of Chemical Engineering, Lagos State Polytechnic, Ikorodu, Lagos, Nigeria. \\ "Lukumon.salami@lasu.edu.ng; SalamiLukumon@yahoo.com
}

Received: $26^{\text {th }}$ May 2017

Accepted: $26^{\text {th }}$ October 2017

Published: $16^{\text {th }}$ March 2018

https://doi.org/10.47545/etrj.2018.3.1.035

\begin{abstract}
Air pollutants are threats to air integrity. The aim of this work is to predict the amount of air pollutants from diesel utilization at Base Transceiver Stations (BTS) in local government areas of Abia State, Nigeria with a view of carrying out one way analysis of variance (ANOVA). The mass flow rate of particulate matter (PM), carbon monoxide (CO), oxides of nitrogen $\left(N O_{x}\right)$ and oxides of sulphur $\left(S O_{x}\right)$ were predicted using the model of Okedere et al. ANOVA was carried out with the aid of in-built solver tool in MicroSoft Excel version 2007. The results obtained ranged between 10.05 and 34.16 tons/yr and between 30.75 and 104.20 tons/yr for PM and CO respectively. The values for oxides of nitrogen varied between 142.86 and 484.13 tons/yr while that of oxides of sulphur ranged between 9.39 and 31.82 tons/yr. The ANOVA result indicated that there were significant differences in the mean air pollutants emitted from BTS at 5\% significant level which implied that the pollutants from BTS in local government areas in Abia State may lead to different health problems. It is pertinent that regulatory agencies and policies makers ensure BTS owners put control in place to minimize the emission of pollutants from BTS.
\end{abstract}

Keywords: Abia state, base transceiver stations, diesel utilization, pollutants, prediction

\section{INTRODUCTION}

Air is made up of a mixture of gases and particulates which have been released into the atmosphere by man - made processes [1]. Contamination occurs when concentration of chemicals, nutrients or elements in the environment becomes more than its normal or natural level as a result of human actions. Contamination is a problem the world is currently battling [2 - 8]. Air pollution is the contamination of air which makes it unfit for living. Over the past few decades, studies have shown that repeated exposures to ambient air pollutants over a prolonged period of time increases the risk of susceptibility to air borne diseases such as cardiovascular disease, respiratory disease and lung cancer [9-10]. Air pollution is a threat not only to living beings but also to plants and vegetations in developed and developing countries.

The telecommunication operators make use of Base Transceiver Stations (BTS) and masts which form part of the infrastructure required for effective telecommunication system [11 - 12]. BTS equipment have to be powered by electricity but because of the epileptic power supply in the country, the BTS are powered by diesel fuelled $27 \mathrm{kVA}$ electric power generators, Every BTS normally have two sets of electric power generators, when one is functioning, the other will be on standby so that no time is lost since there is no guarantee of stable supply of electricity from the national grid [12]. The combustion of diesel emits pollutants which include oxides of nitrogen (NOx), oxides of sulphur (SOx), particulate matter (PM) and carbon monoxide (CO) [12 - 14]. 
Several researchers have worked on air pollution. The examination of concentrations of pollutants and their effects on environment have been carried out by some scholars [15 - 18]. Kanchan and Pramila (2015) [9] reviewed air quality indexing system. The review revealed various indices used by different countries for computing air quality. Okedere et al. (2016) [12] estimated air pollutants from utilization of diesel as energy source at BTS in Nigeria. The work revealed that there was significant increase in the annual amount of pollutants released from BTS into the Nigeria's air shed as a result of increase in diesel consumption. However, the work did not estimate the amount of air pollutants from diesel utilization as energy source at BTS in each state of Nigeria. It is very essential that the amount of air pollutants from diesel utilization as energy source at BTS in each state of Nigeria are known for state environmental protection agencies to take necessary decisions and actions for the protection of environmental integrity. Therefore, the aim and object of this work is to predict the amount of air pollutants from diesel utilization at BTS in local government areas of Abia State, Nigeria with a view of carrying out one way analysis of variance (ANOVA). It is imperative that the prediction of the amount of air pollutants from diesel utilization at BTS in local government areas of Abia State is carried out in order to make available fundamental air pollutants data base which can be used by chemical engineers, environmental engineers, scientist, regulatory bodies and other users of such materials who might work on pollutants from diesel utilization at BTS which justifies this work. Moreover, if the amount of air pollutants from BTS in Abia State contributes to the Nigeria's air shed is established, it will help the authorities and policy makers to put in place environmental policies and plans to mitigate the pollutants which further justifies this work.

\subsection{The Study Area}

Abia State was created on August 27, 1991 with its capital in Umuahia. It is an acronym formed from the initial letters of four groups of people: Aba, Bendel, Isuikwuato and Afikpo (Nigeria Galleria, 2017). Abia State is situated between latitudes $04^{0} 45^{\prime}$ and $6^{0} 07^{\prime}$ north and longitude $07^{\circ} 00^{\prime}$ and $08^{0} 10^{\prime}$ east. It is located in the south - eastern geo - political region of Nigeria and bounded at the west by Imo State, at the south by River State, at the north by Anambra and Ebonyi State and at the east by Cross - River State [11]. Abia State covers an area of about 5,243 square kilometers which is approximately 5.8 percent of the total land area of Nigeria [19] and has seventeen local government areas. The map of Nigeria and map of Abia State showing the seventeen local government areas are presented in Figure 1.

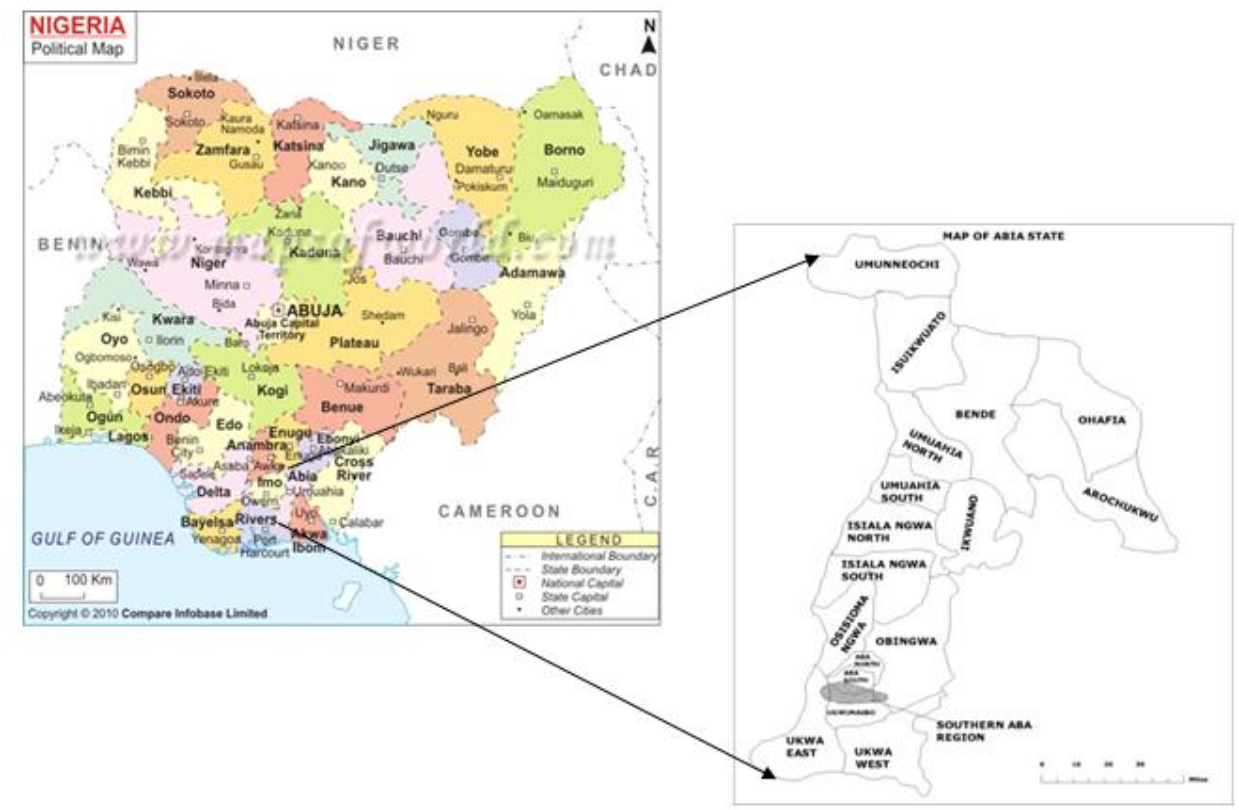

Fig. 1. Map of Nigeria and map of Abia State

Source: Ogbonna et al., (2016) [11] and Ministry of Land and Urban Planning, Abia State, Nigeria (2017) [20]. 


\section{METHODOLOGY}

The reported industry figure of 1 gallon of diesel consumed per BTS generator per hour [12] was used. The flow rate of $\mathrm{PM}, \mathrm{SO}_{\mathrm{x}}, \mathrm{CO}$ and $\mathrm{NO}_{\mathrm{x}}$ for each of the local government in Abia State were predicted using the model of Okedere et al., 2016 [12] shown in Equations $1-4$. The values of D were obtained by multiplying the number of base stations in each local government shown in Table 1 which was taken from the work of Ogbonna et al., 2016 [11] by 3. One way analysis of variance was carried out on the flow rate data obtained using the in-built solver tool in Microsoft Excel version 2007.

$\mathrm{PM}$ (tons $\backslash \mathrm{yr})=\mathrm{D} \times(42.5 \mathrm{lbs} \mathrm{PM} \backslash 1000$ gallons of diesel $) \mathrm{x}(8760 \mathrm{hrs} \backslash \mathrm{yr}) \mathrm{x}(1$ ton $\backslash 2000 \mathrm{lbs})$

$\mathrm{SO}_{\mathrm{x}}$ (tonslyr $)=\mathrm{D} \times(39.7 \mathrm{lbs} \mathrm{SO} \times 1000$ gallons of diesel $) \times(8760 \mathrm{hrs} \backslash \mathrm{yr}) \mathrm{x}(1 \mathrm{ton} \backslash 2000 \mathrm{lbs})$

$\mathrm{CO}($ tonslyr $)=\mathrm{D} \times(130 \mathrm{lbs} \mathrm{CO} \backslash 1000$ gallons of diesel $) \times(8760 \mathrm{hrs} \backslash \mathrm{yr}) \times(1$ ton $\backslash 2000 \mathrm{lbs})$

$\mathrm{NO}_{\mathrm{x}}($ tonslyr $)=\mathrm{D} \mathrm{x}\left(604 \mathrm{lbs} \mathrm{NO}_{\mathrm{x}} \backslash 1000\right.$ gallons of diesel $) \mathrm{x}(8760 \mathrm{hrs} \backslash \mathrm{yr}) \mathrm{x}(1$ ton $\backslash 2000 \mathrm{lbs})$

Table 1. Distribution of BTS by local governments in Abia State, Nigeria

\begin{tabular}{cc|c|c}
\hline S/N & Local government & Number of base stations & Percentage \\
\hline 1 & Aba North & 54 & 8.64 \\
2 & Aba South & 61 & 9.76 \\
3 & Arochukwu & 29 & 4.64 \\
4 & Bende & 36 & 5.76 \\
5 & Ikwuano & 48 & 7.68 \\
6 & Isiala Ngwa North & 33 & 5.28 \\
7 & Isiala Ngwa South & 39 & 6.24 \\
8 & Isuikwato & 21 & 3.36 \\
9 & Obi Ngwa & 36 & 5.76 \\
10 & Ohafia & 27 & 4.32 \\
11 & Osisioma & 41 & 6.56 \\
12 & Ugwunagbo & 28 & 4.48 \\
13 & Ukwa East & 27 & 4.32 \\
14 & Ukwa West & 25 & 4.0 \\
15 & Umuahia North & 53 & 8.48 \\
16 & Umuahia South & 49 & 7.84 \\
17 & Umunneochi & 18 & 2.88 \\
\hline
\end{tabular}

\section{RESULTS AND DISCUSSION}

Table 2 presents the numerical values of pollutants from BTS in local government areas of Abia State, Nigeria. The standard characteristics of diesel stipulated by the department of petroleum resources are assumed in this work. The values of particulate matter ranged between 10.05 and 34.16 tons/yr with Aba South and Umunneochi having the highest and least value of 34.16 and 10.05 tons/yr respectively. This is due to the fact that Aba South and Umunneochi have the highest and least number of base stations of 61 and 18 respectively. Most particulate matters are resulted from incomplete combustion of hydrocarbons in the fuel [21]. The formation process of particulate emissions is dependent on combustion and expansion process, fuel quality, combustion temperature and exhaust gas cooling [21-22].

Particulate matter emissions when inhaled may cause health problems such as premature death, asthma and lung cancer [21]. Particulate emissions contribute to pollution of air, water, soil, cause reductions in visibility and global climate change [23 - 25].This indicates that the people in Aba South local government of Abia state have a higher chance of developing health problems associated with particulate matter emissions from BTS than those in Umunneochi local government of Abia State because of the amount of particulate matter emissions from Aba South which is thrice the amount from Umunneochi. 
The numerical values of carbonmonoxide varied between 30.75 and 104.20 tons/yr with Aba South and Umunneochi local government having the highest and least value respectively. Carbonmonoxide occurs as a result of incomplete combustion that is the oxidation process of incomplete. it is a strong reducing agent and capable of reducing metallic oxides to trheir metals. It combines with haemoglobin to produce carbon - oxyhaemoglobin which causes seizure, coma and fatality [26]. People in Aba South are more prone to health problems resulting from carbonmonoxide because Aba South has the highest value of carbonmonoxide emissions.

The values of oxides of nitrogen ranged between 142.86 and 484.13 ton/yr. Ibrahim et al., 2014 revealed that oxides of nitrogen content in exhaust of diesel engine has the highest percentage among the pollutants emissions. This work also corroborated the findings of Ibrahim et al., 2014 as the values of oxides of nitrogen among the pollutants investigated are the highest in each of the local government. Oxides of nitrogen emissions

Table 2. Numerical values of pollutants from BTS in local government areas of Abia State, Nigeria

\begin{tabular}{c|c|c|c|c|c}
\hline \multirow{2}{*}{ S/N } & Local Government Area & \multicolumn{4}{|c}{ Ton/yr } \\
\cline { 3 - 5 } & & $\mathrm{PM}$ & $\mathrm{CO}$ & $\mathrm{NO}_{\mathrm{x}}$ & $\mathrm{SO}_{\mathrm{x}}$ \\
\hline 1 & Aba North & 30.16 & 92.24 & 428.51 & 28.16 \\
2 & Aba South & 34.07 & 104.20 & 484.13 & 31.82 \\
3 & Arochukwu & 16.20 & 49.54 & 230.16 & 15.12 \\
4 & Bende & 20.10 & 61.50 & 285.72 & 18.78 \\
5 & Ikwuano & 26.81 & 82.00 & 380.95 & 25.04 \\
6 & Isiala Ngwa North & 18.43 & 56.37 & 261.91 & 17.21 \\
7 & Isiala Ngwa South & 21.78 & 66.62 & 309.8 & 20.34 \\
8 & Isuikwato & 11.73 & 35.87 & 166.67 & 10.95 \\
9 & Obi Ngwa & 20.10 & 61.50 & 285.72 & 18.78 \\
10 & Ohafia & 15.08 & 46.12 & 214.29 & 14.08 \\
11 & Osisioma & 22.90 & 70.04 & 325.40 & 21.39 \\
12 & Ugwunagbo & 15.64 & 47.83 & 222.23 & 14.61 \\
13 & Ukwa East & 15.08 & 46.12 & 214.29 & 14.08 \\
14 & Ukwa West & 13.96 & 42.71 & 198.41 & 13.04 \\
15 & Umuahia North & 29.60 & 90.53 & 420.64 & 27.65 \\
16 & Umuahia South & 27.36 & 83.70 & 388.89 & 25.56 \\
17 & Umunneochi & 10.05 & 30.75 & 142.86 & 9.39 \\
\hline
\end{tabular}

contribute to formation of ozone, acidification and smog formation which have become considerable problems in most major cities of world [21]. Oxides of nitrogen are referred as nitrogen (II) oxide (NO) and nitrogen (iv) oxide $\left(\mathrm{NO}_{2}\right)$. NO constitutes $85-95 \%$ of $\mathrm{NO}_{\mathrm{x}}$ and is converted to $\mathrm{NO}_{2}$ in the atmospheric air [21]. However there is a distinctive differences between $\mathrm{NO}$ and $\mathrm{NO}_{2}$. No is a colourless and odorless gas while $\mathrm{NO}_{2}$ is a reddish brown gas with pungent odour [27 - 29].

Oxides of sulphur or sulphur (iv) oxide are formed during combustion process in the generators because of presence of sulphur content in the fuel. The numerical values of oxides of sulphur varied between 9.39 and 31.82 tons/yr with Aba South and Umunneochi having the highest and least value of 31.82 and 9.39 tons/yr respectively. The highest value of 31.82 tons/yr of oxides of sulphur from Aba South local government is due to the highest number of base stations presence in Aba South among all the local government in Abia State. Sulpur (iv) oxide is a colourless and poisonous gas with a very irritating smell like that of burning matches. It is very soluble in water and about 2.5 times denser than air [30].

The pollutants from BTS have very serious environmental implications hence they should be controlled. The particulate matter can be controlled with the use of particulate filters which are used to remove particulate matter emissions from exhaust gas by physical filtration. The filters are attached to exhaust channel and the particulate matters pass through the porous substrate walls which act as mechanical filters as shown in Figure 2 . The soot particles are transported into the pore walls by diffusion as they pass through the wall and they adhere [29]. 
Oxides of nitrogen emissions can be minimized by hydrocarbon selective catalytic reaction (HC - SCR). The most promising catalyst for $\mathrm{HC}-\mathrm{SCR}$ is $\mathrm{Ag}-\mathrm{Al}_{2} \mathrm{O}_{3}$ [29]. Hydrocarbons such as ethanol, acetone and propanol are used as reductants. They are injected into the exhaust stream to aid reduction of oxides of nitrogen. Oxides of Sulphur emission can be minimized using exhaust gas scrubber technology. The exhaust gas is passed through the scrubber tower where a liquid which is a blend of fresh water and caustic soda is showered over it. Carbonmonoide can be controlled using diesel oxidation catalyst (DOC) method. DOC oxidizes carbonmonoxide emissions. Diesel exhaust gases contain oxygen ranging from 2 to 17 percent by volume which does react with fuel in the combustion chamber and it is consumed in DOC [28, 31]. Above all, the best way to avoid pollutants from BTS is to do away with fossil fuel. Nigeria should improve on its electricity generation so that users of BTS can rely on electricity from national grid.

Analysis of variance is a collection of statistical models used to analyse the differences among group means and their associated procedures that is it provides a statistical test of whether or not the means of several groups are equal. The values of $\mathrm{F}$ and $\mathrm{F}$ critical in this work were 5.7 and 2.75 respectively at $5 \%$ significant level $(\alpha=5 \%)$. Hence null hypothesis $\left(\mathrm{H}_{\mathrm{o}}\right.$ is rejected. This implied that there were significant differences in the mean pollutants emitted from BTS by combustion of diesel in local government areas of Abia State at 5\% significant level. This further implies that the pollutants emitted from BTS in Abia State may result to different health problems

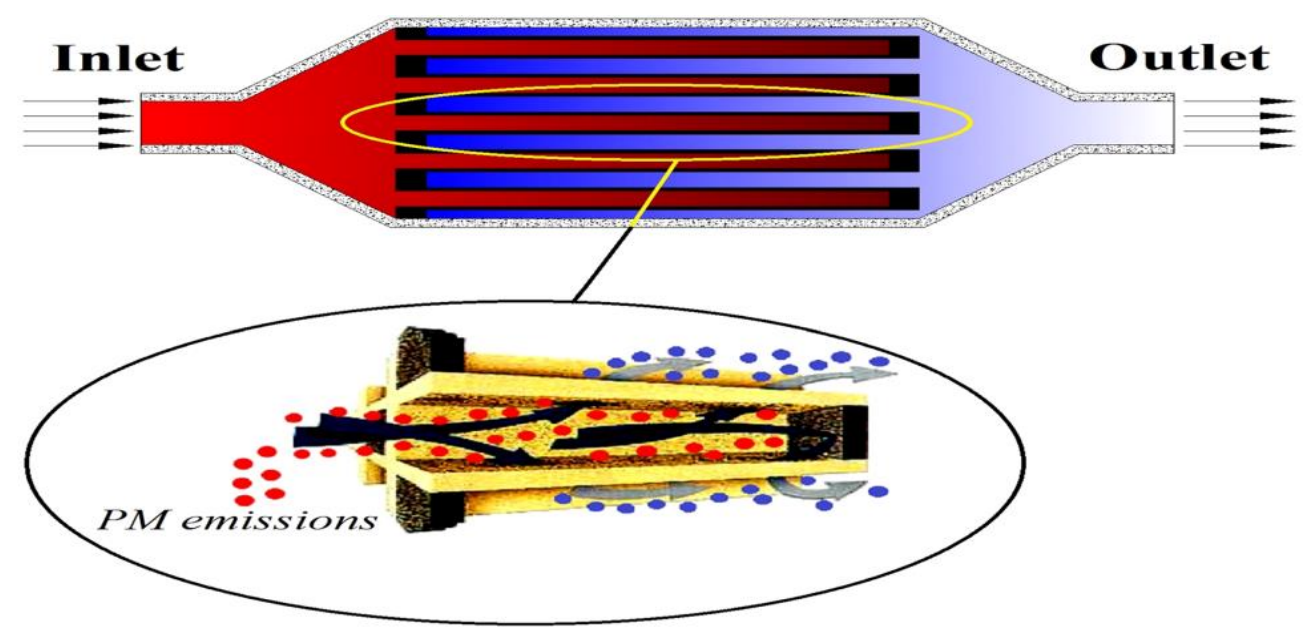

Fig. 2: Filtration of particulate filter (Source: Ibrahim et al., 2014) [28].

.Table 3. Analysis of variance of pollutants from diesel utilization in BTS in Abia AState

\begin{tabular}{|c|c|c|c|c|c|}
\hline Sources of variation & Sum of square & Degree of freedom & Mean square & F & Fcritical \\
\hline Between treatment & 44,925 & 3 & 14,975 & 5.70 & 2.75 \\
Residue & $168,148.50$ & 64 & $2,627.32$ & & \\
Total & $213,073.50$ & 67 & & \\
\hline
\end{tabular}

\section{CONCLUSION}

The air pollutants from diesel utilization at BTS in local government areas of Abia State have been predicted. The numerical values of particulate matter ranged between 10.05 and 34.16 tons/yr while that of carbonmonoxide varied between 30.75 and 104.20 tons/yr. T he numerical values of oxides of nitrogen ranged between 142.86 and 484.13 tons/yr which were higher than values of oxides of sulphur that varied between 9.39 and 31.82 tons/yr. ANOVA result revealed that there were significant differences in the mean pollutants emitted from BTS due to combustion of diesel in local government areas of Abia State at 5\% significant level. The implication of this is that the pollutants 
from BTS in Abia State may also lead to different health problems. It is pertinent that the regulatory agencies and policies makers ensure BTS owners put in place control measures which have elucidated in this work to minimize the emission of airf pollutants from BTS.

\section{REFERENCES}

1. Air pollution guild (2015). Available at http://www.rrcap.ait.asia/male/base/action plan/wepa/NEPCHB.htm. Accessed June 26, 2015.

2. M. M. Mortula and R. S. Rahman, "Study on waste disposal at DEPZ". Bangladesh Environment, Vol. 2, $2002,807-817$.

3. A. A. Adeniyi and J. A. Afolabi, "Determination of total petroleum hydrocarbons and heavy metals insoil within the vicinity of facilities handling refined petroleum products in Lagos Metropolis". Environmental International, Vol. 28, 2002, $79-82$.

4. M. G. M. Alam, E. T. Snow and A. Tanaka, "Arsenic and heavy metals concentration of vegetables grown in Samta village, Bangledesh”. Science of Total Environment, Vol. 111, 2013, 811 - 815.

5. M. Arora, B. Kiran, A. Rani, S. Rani, B. Kaur and M. Mittal, "Heavy metal accumulation in vegetables irrigated with water from different sources". Food Chemistry, Vol. 111, 2008, $811-815$.

6. H. Lim, J. Lee, H. Chon, and M. Sager, M. "Heavy metal contamination and health risk assessment in the vicinity of the abandoned Songcheon Au-Ag Mine in Korea". Journal of Geochemical Exploration, Vol. $96,2008,223-230$.

7. G. Ahmed, M. K. Uddin, G. M. Khan, M. S. Rahman, D. A. Chowdhury, "Distribution of trace metal pollution in surface water system connected to effluent disposal point of Dhaka Export Processing Zone (DEPZ), Bangladesh: A statistical approach". Journal of National Science and Technology, Vol. 3, 2009, : $293-304$.

8. M. A. H. Bhuiyan, N. I. Suruvi, S. B. Dampare, M. A. Islam, S. B. Quaraishi, S. Ganyaglo, and S. Suzuk, "Investigation of the possible sources of heavy metals contamination in Lagoon and canal water in the tannery industrial area in Dhaka, Bangladesh”. Environmental Monitoring Assessment, Vol. 175, 2011,633 -649 .

9. A. K. G. Kanchan, and G. Pramila,." A review of air quality indexing system". Asia Journal of Atmospheric Environment, Vol. 105, 2015, 101 - 103.

10. World Health Organization (WHO). Global health risk: Mortality and burden of diseases attributed to selected major risk, 2009. Available at http://www.int/healthinfo/global-burden-disease/global health riskreport. Accessed date: June, 2014.

11. C. G. Ogbonna, V. U. Okeye and E. I. Eleazu, "Telecommunication masts/base transceiver stations and regulatory standards in Abia State, Nigeria", Journal of Sustainable Development, Vol. 9 (6), 2016,46 57.

12. B. Okedere, B. S. Fakinle and J. A. Sonibare, "Ground level concentrations of hydrocarbon emission from diesel fuelled electric power generators”. Global NEST Journal, Vol. 17(4), 2016, 673 - 681.

13. S. S. Fakinle,J. A. Sonibare, F. A. Akeredolu, O. B. Okeder, and L. A. Jimoda, "Toxicity potential of particulate in the air shed of haulage Vehicle Park". Global NEST Journal, Vol. 15(4), 2013, 466 - 473. 
14. O. B. Okedere, J. A. Sonibare and L. A. Jimoda, "Annual estimation of iar pollutants from utilization of diesel as energy source at base transceiver stations in Nigeria". Journal of The Nigerian Society of Engineers, Vol. 51(2), 2006, 38 - 48.

15. F. U. Akeredolu, A. F. Oluwole, E. A. Betiku and O. J. Ogunsola, "Modelling of carbonmonoxide concentration for motor vehicles travelling near roadway intersection in Lagos, Nigeria". $2^{\text {nd }}$ International Conference on air pollution, Barcelona, 1994.

16. R.W. Bouble, D. L. Fox, D. B. Turner, A. C. Stern, "Effect on materials and structures". Fundamentals of air pollution. Academic Press, New York, 1994.

17. O. R. Awofolu, "Implication of automobile exhaust on level of lead in a commercial food from bus terminals". Journal of Applied Science and Environmental Management. Vol. 8(1), 2004, 23 - 26.

18. S. I. Efe, "Spatial distribution of particulate in air pollution in Nigeria cities: Implications for human health". The Environmentalist, Vol. 7(2), 2008.

19. Nigeria Galleria. "Brief Histroy of Abia State". Available at Nigeria Galleria.com. 2017, Accessed March 17,2018

20. Ministry of Land and Urban Planning, Abia State, Nigeria. "Map of Abia State, Nigeria”. 2017.

21. A. R. Ibrahim, A. Kemal, and K. Ali, "The pollutants emissions from diesel-engine vehicles and exhaust after treatment systems". Clean Technology Environment Policy, Vol. 17, 2015, 15 - 27.

22. H. Burtscher, "Physical characteristics of particulate emissions from diesel engines: A review". Aerosl Science, Vol. 36, 2005, $896-932$.

23. R. A. Michael and M. T. Kleinman, "Incidence and apparent health significance of brief air borne particle excursions". Aerosol Science Technology, Vol. 32, 2000, 93 - 105.

24. N. Englert, "Fine particle and human health: A review of epidemiological studies". Toxicology, Vol. 149, $2004,235-242$.

25. Organisation for Economic Co-operation and development (OECD), "Strategies to reduce greenhouse gas emissions from road transport: Analytical methods". OECD, Paris. 2012.

26. A. Rim-Rukeh, "An assessment of the contribution of municipal solid waste dumpsites fire to atmospheric pollution". Journal of air pollution. Vol. 3, 2014, $53-60$.

27. J. J. Chong, A. Tsolakis, S. S. Gill, K. Theinnoi, S. E. Golunski, "Enhancing the $\mathrm{NO}_{2} / \mathrm{NO}_{\mathrm{x}}$ ration in compression ignition engine by hydrogen and reformate combustion from improved after treatment performance”. International Journal of Hydrogen Energy, Vol. 35, 2010, 8723 - 8732.

28. A. R. Ibrahim, A. Kemal, K. Ali, "The polluatant emissions from diesel-engine vehicles and exhaust after treatment systems". Clean Technology Environment Policy, Vol. 17, 2015, 15 - 27.

29. S. K. Hoekman and C. Robbins, Review of the effects of biodiesel on NOx emissions. Fuel Process Technology, Vol. 96, 2012, 237 - 249.

30. L. Salami. and M. O. Odunlami, “Air quality assessment of Soluos dumpsite”. Nigeria Journal of Industrial Studies, Vol. 12(1), 2015, : $1-9$. 
31. B. K. Yu and M. Y. Kim, "Modeling the selective catalytic reduction of $\mathrm{NO}_{\mathrm{x}}$ by ammonia over a vanadia based catalyst from heavy duty diesel exhaust gases". Applied Thermodynamics Engineering, Vol. 50, $2013,152-158$ 